\title{
THE SERVANT'S TALE: HOW REBEKAH FOUND A SPOUSE
}

\author{
JACK M. SASSON, Vanderbilt University
}

\author{
To Jean-Marie Durand, \\ first to reveal the full Halab story
}

\section{INTRODUCTION}

W HAT first drew my attention and curiosity about Genesis 24 and its story of how Isaac got a spouse was a line that may seem benign. We are told in verse 65 that upon learning that she had her future husband in her sight, Rebekah "grasped her veil to cover herself" (ותקח הצעיף ותתכס). An act of modesty, agree most commentators, who also observe that, in fact, veiling is not the normal appearance of a Hebrew married woman. ${ }^{1}$ Near Eastern testimony, however, does suggest that in many cultures brides may have been veiled, by a husband or his proxy, a nonverbal act that may be read symbolically (possession by a groom) or metaphorically (a hymen, to be broken by a groom). ${ }^{2}$ The curiosity here is about Rebekah's veiling: it is attributed neither to Abraham's servant when in the city of Nahor (Haran) nor to Isaac as his bride came to him. Recovering the import of Rebekah's self-veiling has led me to review Genesis 24 in the light of marriage conventions obtaining among the elites of the ancient Near East.

\section{THE BACKGROUND}

\section{THE UNIQUENESS OF ISAAC}

The "Wooing of Rebekah" is set midway in Genesis and unravels itself over a great number of verses. ${ }^{3}$ As developed in the received version of Hebraic history, it also bridges

${ }^{1}$ Eli could not have seen Hannah's lips moving in prayer (1 Sam. 1) and Abraham would not have feared Sarah's beauty inflaming others (Genesis 12, 20) were Hebrew women veiled. Over time, clothing and grooming likely differed regionally if not also among social classes. Muslim women differentiate among a variety of headdresses to accord with modesty (hijāb). Some cover the top of the head but not the face; others hide most of the face except for eye slits. Fabrics also differ, making some sheerer than others.

2 The material and bibliography are most recently assembled in K. van der Toorn's, "The Significance of the Veil in the Ancient Near East," in David P. Wright

[JNES 65 no. 4 (2006)]

(C) 2006 by The University of Chicago.

All rights reserved.

0022-2968-2006/6504-0001\$10.00. et al., eds., Pomegranates and Golden Bells: Studies in Biblical, Jewish, and Near Eastern Ritual, Law, and Literature in Honor of Jacob Milgrom (Winona Lake, Indiana, 1995), pp. 327-39. To his collection of evidence, we might add now a fine Old Assyrian example from text no. 399 in Cécile Michel, Correspondance des marchands de Kaniš au début du $I I^{e}$ millénaire avant J.-C., Littératures anciennes du Proche-Orient (LAPO) 19 (Paris, 2001). A Mari king, giving up on keeping his unhappy daughter at her husband's side, finally instructs her, "Cover your head and leave" (ARM $1076: 8$ and ARM 2 113:6, both reedited in J.-M. Durand, Documents épistolaires du palais de Mari, vol. 3, LAPO 18 [Paris, 2000], nos. 1243-44, pp. 466-71 [hereafter LAPO 18]).

3 Deuteronomy 28 has slightly more verses (69) than Genesis 24. Numbers 7, at 89 verses, is the longest in the Pentateuch, but verse segmentation is post-fifteenth 
two biographies, that of Abram/Abraham, in which Israel's entitlement to a significant portion of the Promised Land is first established, and that of Jacob (itself incorporating Joseph's), in which the gains are almost lost. ${ }^{4}$ It also bridges two themes: the promise of continuity, featured in the Abraham narratives, and the guidance of Providence, strongly controlling the activities of Jacob and Joseph. Isaac's own narratives either replay episodes of his father's (his involvements with Abimelech of Gerar) or are a prelude to the drama that comes to be Jacob's life (the tension between the twin sons). Yet it cannot be said that Isaac is a lesser figure, if only because everything about his life turns him into a perfect emblem for the unfolding of the promise: his birth is near miraculous $(18: 1-15 ; 21: 1-7)$, he is the first of his people to embody the covenant of infant circumcision (17,21:4), he is selected by his father over his older brother (21:8-21), and he is the instrument by which God tests Abraham's faith (22). It makes sense, then, that Isaac is unique among the patriarchs never to leave the Promised Land, to gain divine help in the search for a worthy wife, and to successfully petition God for an end to his wife's sterility $(25: 21){ }^{5}$

\section{RECOUNTING HOW ISAAC AND REBEKAH MARRIED}

In the literature about Genesis 24, there are many testimonies to the beauty of its prose and to the distinct pace with which the story of Isaac's marriage unfolds. ${ }^{6}$ I can cite many fine introductions to it, but perhaps that of Skinner may do:

The chapter is one of the most perfect specimens of descriptive writing that the Book of Gen. contains. It is marked by idyllic grace and simplicity, picturesque elaborations of scenes and incidents, and a certain 'epic' amplitude of treatment, seen in the repetition of the story in the form of speech. . . . It may be conjectured that the basis of the narrative was a reinforcement of the Aramæan element in the Hebrew stock, as in the kindred story of Jacob and his wives... . But if such a historical kernel existed, it is quite lost sight of in the graphic delineation of human character, and of ancient Eastern life, which is to us the main interest of the passage. We must also note the profoundly religious conception of Yahwe's providence as an unseen power, overruling events in answer to prayer. ${ }^{7}$

century C.E., with chapter division two centuries earlier. It may be more correct to say, therefore, that the story is among the longest single episodes in Scripture. Midrash Genesis Rabbah (60:8, on Gen. 24:32) cites Rabbi Aha's puzzlement about taking so much space to develop this story when weighty halachic decisions (such as at Lev. 11:19) may ride on a single consonant!

${ }^{4}$ I discuss this biographical mode of reporting history, most recently, in "History as Literature in Ancient Israel," in Hebrew Origins, The Chen King Lectures (Hong Kong, 2002), pp. 2-24.

5 In contrast, Abraham remains steadily skeptical of his wife's capacity to bear children, and Jacob simply refuses to force God's interference in Rachel's case (30:2).

${ }^{6}$ Genesis 24 is difficult to date with scholars setting its (final) version anywhere within the Canaanite and Hellenistic periods. Fortunately, the issue is not of direct importance to this study. Arguments have depended on such matters as the alleged cultural affinities between tribal Israel and second-millennium Syro-Mesopotamia and the domestication of the camel (see below). The most sustained dispute now is largely based on identifying Aramaisms in it. A. Rofé champions a Persian period for the writing of the story, most recently in "An Inquiry into the Betrothal of Rebekah," in Erhard Blum, Christian Macholz, and Ekkehard W. Stegemann, eds., Die Hebräische Bibel und ihre zweifache Nachgeschichte: Festschrift für Rolf Rendtorff zum 65. Geburtstag (Neukirchen-Vluyn, 1990), pp. 27-39. Gary A. Rendsburg uses the same evidence to set the story in the mid-ninth century in "Some False Leads in the Identification of Late Biblical Hebrew Texts: The Cases of Genesis 24 and 1 Samuel 2:27-36," Journal of Biblical Literature (JBL) 121 (2002): 23-36. His opinion that a narrator purposely constructed Aramaisms "to provide an Aramean coloring for a story set in Aram" (p. 31) depends on a historicizing (not to be confused with a purposefully archaizing) consciousness that is scarcely credible for ancient authors.

7 John Skinner, A Critical and Exegetical Commentary on Genesis, $2 \mathrm{~d}$ ed. International Critical Commentary (Edinburgh, 1930), pp. 339-40. Lieve M. Teugels offers a monograph treatment of the story, Bible and Midrash: The Story of 'The Wooing of Rebekah' (Gen. 24), Contributions to Biblical Exegesis and Theology 35 (Leuven, 2004). 
What has not been adequately promoted is how much this accounting of a marriage differs from other information on Hebrew marriage customs and rituals. In prophetic and wisdom literatures references to marriage teach lessons about constancy and fortitude, while in erotic literature they sharpen the emotions. In the "legal" material, however, women can be forced to marry the person who buys them from their fathers (Exod. 21:7-11), the enemy who captures them in war (Deut. 21:10-14), the scoundrel who rapes them (Exod. 22:15-16), and the brother of their infertile dead husbands (Deut. 25:5-10). In such cases, and despite Gen. 2:24, it is the wife who enters her husband's home.

\section{MARRIAGES IN BIBLICAL NARRATIVES}

In anecdotes and narratives, marriages can also be initiated by grooms, for example by Esau (Gen. 26:34-35; 28:6-9), Shechem (Gen. 34:4), Judah (Gen. 38:2), Joseph (Gen. 41:45), Samson (Judg. 14:2), and David (many cases, including after adultery, 2 Sam. 11). Marriages that are said to be arranged by parents, however, further themes beyond the immediate contexts: Hagar takes an Egyptian wife for her son Ishmael (Gen. 21:21); Hamor tries to wed Jacob's daughter to his son Shechem, with disastrous results (Genesis 34); Judah almost compromises his own future by securing marriage for his sons (Gen. 38:611); Samson's parents are mere tools for God when they seek a bride for their son (Judg. 14:2-7). Notices about marriage can also enrich contexts or conditions: Caleb promises Achsah to a conqueror of a specific city (Josh. 15:16-17 = Judg. 1:12-13), and Saul makes David a similar offer, dependent on defeating his foes (1 Sam. 18). An interesting subgenre is the desire of a courtier to marry a concubine of a former king, with unhappy consequences for the suitor (Abner wants Rizpah, 2 Samuel 3; Adonijah pines for Abishag, 1 Kings 2).

Most often brought into comparison with the nuptials in Genesis 24, however, are two episodes involving runaway heroes (Jacob, Moses) who leave their own borders and meet their future spouses by a well (Rachel, eventually also Leah, Zipporah). These stories do indeed share the motifs (even the syntax of these motifs) that occur also in such Near Eastern tales as The Fated Prince (Egypt) and Keret/Kirta (Ugarit): travel to the land or city of the future bride, providential help, the timely arrival of the future (beautiful and thoughtful) bride, negotiations for the bride, blessings, and return with the bride. ${ }^{8}$ But the narrative in Genesis 24 differs in a conspicuous manner: the groom is not the hero of the search; in fact, he fades into the background as his representative takes over the task of identifying, negotiating for, and securing the bride. ${ }^{9}$ Such a pattern, in which troth is negotiated by a surrogate or a proxy, is known to the ancient world, occurring when rulers bolstered their political advantage by marrying themselves or their sons to daughters of other rulers.

\footnotetext{
${ }^{8}$ Robert Alter applied to this pattern of motifs the label "betrothal type-scene" (imported from Homeric scholarship), and this has stuck in scholarship, The Art of Biblical Narrative (New York, 1981), pp. 50-62; $\checkmark$ see Teugels, Bible and Midrash, pp. 51-57. Simon B. Parker, "The Marriage Blessing in Israelite and Ugaritic Literature," JBL 95 (1976): 23-30, and Kenneth T. Aitken, "The Wooing of Rebekah: A Study in the Development of the Tradition," Journal for the Study of the Old Testament (JSOT) 30 (1984): 3-23, bring the Ugaritic material into sharp comparison. How Ruth got herself a husband might be included among the
}

"betrothal type-scene": she crossed borders and met Boaz, not around a well but at the threshing floor, another communal spot.

${ }^{9}$ Many have observed that the accumulation of motifs in Genesis 24 differs from those told about Jacob and Moses by the role played by the groom's proxy and by the water-drawing activity of the future bride rather than the groom. This tendency is to consider these changes as variations in the betrothal type-scene, but there are also theologically driven explanations that make the servant a tool of Yahweh. On all this, see Teugels, Bible and Midrash, pp. 55-57. 


\section{INTERDYNASTIC MARRIAGES}

The calculated steps in interdynastic marriages cannot have been new when we first learn about them in political exchanges from antiquity, and they are deployed not much differently when recalled in literary or artistic accounting deep into our own times. ${ }^{10}$ As far as the ancient Near East is concerned, we are especially well informed on negotiations during the Amarna period (mid-second millennium B.C.E.), when conveying brides across frontiers was characteristic of a true internationalism. ${ }^{11}$ But I prefer to cite material from Mari not only because I know its archives better but also because the epistolary origin of the information gives it an intimacy lacking in other examples. We have details on the marriages of a number of Mari princesses to vassals of their father, King Zimri-Lim, but the correspondence on the betrothal of Zimri-Lim himself to Princess Šiptu is for us the most instructive. ${ }^{12}$

\section{A Betrothal in Halab}

Within months of taking over power at Mari, Zimri-Lim (ca. 1775-1761 B.C.E.) sought stability for his throne by suing for the daughter of Yarim-Lim of Yamhad. Zimri-Lim himself was no youngster when he made his move, as he already had a number of marriageable daughters. The king charged two trusted members of his inner circle with bringing back the bride: his chief musician (and likely harem keeper), Rišiya, and Asqudum, his diviner as well as his brother-in-law. I cite and annotate as appropriate three letters the two delegates sent their king, the first written soon after their arrival to Yamhad's capital, Halab (Aleppo). Although the letters are sent by the two, frequently they carry the voice of a

10 Vittore Carpaccio's 1490s series of paintings for the Scuola di Sant'Orsola in Venice (http://gallery. euroweb.hu/html/c/carpacci/1 ursula/index.html), now mostly in the Gallerie dell'Accademia, is about the life and martyrdom of Saint Ursula; but it actually draws on the extended (1468-72) negotiations for the nuptials of the Venetian Caterina Cornaro to James (II) de Lusignan, future king of Cyprus. They include arrivals and departures of ambassadors, exchanges of terms, and elaborate travel arrangements for the betrothed. An agreeable conjunction between the negotiations and Carpaccio's artistic vision of events is in Garry Wills's Venice, Lion City: The Religion of Empire (New York, 2001), pp. 135-47. The Cornaro story inspired operas by Franz Lachner (1841) and Gaetano Donizetti (1844).

${ }^{11}$ Two excellent essays with relevant bibliography are by K. Avruch, "Reciprocity, Equality, and StatusAnxiety in the Amarna-Letters," and by S. A. Meier, "Diplomacy and International Marriages: Amarna Diplomacy," pp. 154-64 and 165-73 respectively, in Raymond Cohen and Raymond Westbrook, eds., Amarna Diplomacy: The Beginnings of International Relations (Baltimore, Maryland, 2000). One of Avruch's points is worth keeping in mind, "Cross culturally speaking ... in fact, wife-givers are usually superior to wife-takers; women in effect 'marry down' (hypogamy)"; p. 63, with a caveat in n. 36 (p. 258). Vassals can give their daughters to the sons of overlords, however, especially if the son is not heir to the throne; see SH 874 = text 60 in J. Eidem and J. Læssøe, The Shemshāra Archives, 1. The Letters, Historisk filisofiske Skrifter 23 (Copenhagen, 2001), pp. 130-31.

In "The Marriage Market" Trevor Bryce offers a readable overview of such marriages during the Amarna period featuring the protracted negotiations that brought one (or two) Hittite princes to Ramses II; see Letters of the Great Kings of the Ancient Near East: The Royal Correspondence of the Late Bronze Age (London, 2003), pp. 113-19. A long list of interdynastic marriages (by no means complete now) is given by W. Röllig, "Heirat" in RLA, vol. 4, pp. 282-87.

12 Two fine overviews of the archives on Mari marriages are Bertrand Lafont's, "Les filles du roi de Mari," in J.-M. Durand, ed., La femme dans le ProcheOrient antique: compte rendu XXXIII ${ }^{e}$, Rencontre Assyriologique Internationale (Paris, 7-10 Juillet 1986) (Paris, 1987), pp. 113-21, and "Relations internationales, alliances et diplomatie au temps des royaumes amorrites: Essai de synthèse," Amurru 2 (2001): 31215. The comments of J.-M. Durand on Šiptu's marriage can still be read with profit, in Archives épistolaires de Mari, I/1, Archives royales de Mari 26/1 (Paris, 1988), pp. 99-106. They are developed in LAPO 18, pp. $165-84$. 
single individual, presumably Asqudum, who seems to dominate the bulk of this correspondence. Also worth observing is the tendency in this correspondence to underplay what is presumed. There is, for example, hardly any mention of the vast personnel (servants and guards) that was assembled to undertake such a voyage. Only on the return trip, with the caravan enlarged by the cortege that then included women attending the princess, do we have hints of occasional logistical problems.

ARM 26:10 Yarim-Lim discussed matters with us: "You did bring the biblum. Yet, because my mother is ill and I fear something awful is about to happen in my palace, you have very little time." Because of this circumstance, we made haste to have the biblum, which our lord conveyed by us, entered (into the palace grounds). Moreover, we draped veils over the young woman.

Within three days after we had had the biblum brought in, Lady Sumunna-abi met her fate. Via (his minister) Ṭâb-balațī, King Yarim-Lim sent us the following message, "Go and tour each of my fortresses and households." We deliberated before responding, "Why would our lord send such a message to us, "Go and tour each of my fortresses and households'?" This is what we answered. Later, we (also) sent the message, "Is Lady Sumunna-abi not our very own lady? If we are not staying by our lord [Yarim-Lim], and this situation becomes known in Mari itself, it would be a scandal. Therefore, allow the servants of your son [Zimri-Lim] to stay with you."

[Yarim-Lim] did not answer me immediately; but he himself sent back his servants with his message," "Have you seen (my land)? Go then." But I answered [few lines missing. The text ends with the ambassadors (?) saying,] ". . . Our lord should convey 20 gold vessels so that they may be deposited in our lord's cellar."

This letter comes from Zimri-Lim's second full year on the throne, but the negotiations may have begun before he fully captured the throne. ${ }^{13}$ We know that a terhatum, the groom's gift to the young woman's father, had been sent a few months earlier, and it included a rich display of jewelry (necklaces, disks, vessels of precious metals, textiles and garments, over a hundred cattle, and a thousand sheep). ${ }^{14}$ The delegates presented the bride's father with the biblum, a package of presents that normally would have been distributed among other members of the family. Due to the impending death of Sumunna-abi (likely the queenmother), however, this step was the minimal necessary before the future bride, not yet identified by name, was veiled. ${ }^{15}$ The squabble that ensued between the delegates and the king is significant. Normally, obsequies are open only to family, and the delegates, fearing a

13 A chronology of events is suggested by Dominique Charpin and Nele Ziegler, in Mari et le ProcheOrient à l'époque amorrite: essai d'histoire politique, Florilegium marianum 5, Mémoires de N.A.B.U. 6 (Paris, 2003), pp. 191-93.

14 ARM 25 616, reedited by J.-M. Durand in ARM $26 / 1$, pp. 100-101. We note that the "bridewealth" is labeled (1. 62) "terhatum for the daughter of YarimLim." The bride to be is not yet named. (See also below.) In contrast, we are missing any information on the nidittum, the "dowry," that Yarim-Lim would have bestowed on his daughter. If custom prevailed, it would have been equivalent in value to the terhatum. (That portions of the terhatum are recycled into the nidittum is likely.) For references to Asqudum's conveyance of the terhatum, see now David Duponchel, "Les comptes d'huile du palais de Mari datés de l'année de Kahat," Florilegium Marianum 3 (1997): 211-12. The elaborate rounds of nuptial gifts continue into our days. When Jews in my community still lived in Aleppo, this practice obtained: the groom gave a gashshe to the bride's parents, a dotta reversed the gift sequence and, during the $s w \bar{e} n \bar{\imath}$ ("trays") ceremonies, groom and bride exchanged gifts. Once transplanted in America, the same community has kept alive only the $s w \bar{e} n \bar{l}$, making it more elaborate, with the groom slipping the bride a bejeweled purse stuffed with cash for the mikvah.

15 In the Amarna period, Egyptian envoys poured oil on destined brides from Babylon, Arzawa, and Hatti; references in Meier, "Diplomacy and International Marriages," pp. 168-69. 
scandal for being sent out of Halab for the duration, argue that (likely because of the veiling) they are now representing a member of the family. But Halab's ways differed, and we follow the matter in another letter sent a fortnight or so later.

ARM 2611 When Lady Sumunna-abi died, Yarim-Lim told us, "Until this funerary vigil runs its course, go (both of you) and make a tour of my country's heartland." For fifteen days we traversed his country's heartland and headed back. Since we have come back, I have made ready the sheep that were previously assigned for the sacrifices of the young woman and the remaining sheep that were left in my charge [when traveling]. There were also:

For Yarim-Lim: 1 gold ring weighing 6 shekels [50 grams]; 1 heavy-textured fabric, 1 first-quality rough-woven fabric; 5 second-quality rough-woven fabrics; 21 second-quality "straight"-woven fabrics; 200 sheep (tišanum and fat-tailed), and birds.

For Gašera [his wife]: 1 finely-woven fabric; 2 gold clasps weighing 2 shekels; 2 gold clasps weighing 1 shekel and [?]+20 sheep.

For the daughter, Šiptu: 1 Marad fabric; 2 gold clasps weighing 2 shekels.

This later presentation, much as the previous one, is sufficient. ... As to Yarim-Lim, he very graciously told me, "Your previous presentation, what should I do (with it)? There has never been (such a display) from any of the kings, (even) now that the kings of the entire country are assembled." 16 For this reason Yarim-Lim is extremely pleased. Moreover, after the donkey sacrifice I shall insist on our leaving promptly. The decision is taken.

From this letter, we learn that the biblum is now fully delivered, and it includes gifts for the bride, now fully named, and for her immediate parents. Earlier, sheep had been delivered "for the sacrifices of the daughter" (1. 16). The phrase is difficult to interpret, but I imagine that the immolations on the part of the bride are symbolic of her acceptance of her new status. It is also possible that the name Šiptu, by which we know the queen of Mari, was assigned to her at that moment, possibly by her husband through a proxy. ${ }^{17}$ An additional letter informs us about the residence of the bride. This time it is sent by Asqudum alone.

ARM 2613 Yarim-Lim took me aside and said, "I keep on hearing: 'the gods are powerful in the palace.' Where will my daughter's belongings enter (into it)?" When I told him, "Your daughter's residence is indeed excellent," he answered, "My daughter's belongings may be stored in her residence, but my daughter must reside with her husband. She may leave for about five to six days to maintain her residence."

Now then, my lord should give orders and have people make ready for his daughter the house of Mut-bisir [a tribal leader]. This way, when his servants who are accompanying me review (it), they can report the matter to their lord. I am now communicating to my lord whatever I heard Yarim-Lim say. My lord should reflect on having people set up the house that they are readying for the daughter. . . ${ }^{18}$

16 This is a difficult passage. The presence of other kings (likely vassals) gave formality to such important occasions. Likewise, kings are witnesses at divorce proceedings; see LAPO 18, no. 1230 (= ARM 10 33), pp. 444-45; cited in $n .61$ below.

17 We might notice that Isaac's name is never communicated to Rebekah or her family, as long as the nuptials are not fully complete. Administrators begin calling Šiptu their "Lady" (bêltum) from this point on (ARM 26 14:8, 16:6 ff.). The etymology of this famous queen's name is still in dispute, possibly šibtu (The
Old Lady, to be understood prophylactically or as soubriquet for authority), šiptu (judgment, verdict) or, less likely, šiptu (incantation, spell). We note that the first two possibilities work equally as Akkadian or Amorite (West Semitic). Changing the name of a princess as she becomes queen is more urgent when the language of her new home differed, as happened to Babylonian and Hittite wives of Egyptian pharaohs.

18 See the proposed readings of J.-M. Durand in “Une maison pour Śiptu à Mari," NABU 2004/52 (p. 53). 
Three matters here are worth noting. First, how solicitous is the bride's father for the wellbeing of his daughter? Yarim-Lim wished to make sure she would have fine living quarters, not at all clear when a women enters a harem. The reason behind this concern may also be practical; the speculation here is that the king wants to raise his daughter's chances of conceiving the future king: Zimri-Lim, as far as we can tell, at that moment had only daughters. ${ }^{19}$ The second matter has to do with the quick wit of Asqudum: he urges ZimriLim to make ready a house for inspection by Yarim-Lim's envoys, for he must know that it does not yet exist. The final observation is tentative, as it arises from the absence of a marriage contract. Perhaps interdynastic marriages did not require them even if divorces did occur in such circles. ${ }^{20}$

There is more correspondence that sheds light on the marriage arrangements of Šiptu. We learn that a whole retinue of women servants and guards accompanied her during her trek to her new home (ARM 26 14-16). Among those who remained permanently with the princess were a courier to relay messages to and from her family, her "mother" (likely her former wet nurse), and a childhood playmate. ${ }^{21}$ Šiptu, however, kept in contact with her own mother, Gašera, who remembered her with gifts and notes (ARM 10 30; 139:11 = LAPO 18, nos. 1190-91, pp. 382-83). Her father would also piggyback gifts to her (20 cows, in FM 2 29) when writing to Zimri-Lim. ${ }^{22}$

What we have learned from this brief excursus on the marriage of Zimri-Lim is that, aside from its long-distance resolution, the process of acquiring a queen required endless time and diplomacy. We read about quick-witted ambassadors, rich gifts, the veiling of a bride,

19 If this assumption is correct, Šiptu is expected to stay with her husband when she is not menstruating. Wolfgang Heimpel objects: "I cannot believe that Yarim-Lim would instruct Ašqudum about such a topic and I assume that the 5 to 6 days refer to the time when his daughter would be allowed to leave Halab, go to Mari, and 'concern herself with her new apartments" "; see Letters to the King of Mari: A New Translation, with Historical Introduction, Notes, and Commentary, Mesopotamian Civilizations 12 (Winona Lake, Indiana, 2003), p. 183. Yarim-Lim certainly hoped that his grandchild would rule Mari, but he must also have cared for his daughter's welfare when, as Mari and Amarna evidence shows, princesses were often neglected in their new surroundings. An interesting letter from a king of Qatna to Yasmah-Addu, his son-in-law and Zimri-Lim's predecessor, displays concerns about welfare and posterity (A.3158, cited from J.-M. Durand, most recently in LAPO 18, no. 1008, pp. 172-74):

I am placing in your lap my flesh and my future. The handmaid that I give you, may God make her attractive to you [ilum hinnaša ana pānīka liddin = similar phrasing in Exod. 11:3 and 12:36]. I am placing in your lap my flesh and future, for this house has now become yours and the house of Mari has now become mine. Whatever you desire, just write me and I will give it to you.

20 We know of a vassal of Zimri-Lim, Ibal-Addu of Ašlakka, who married Inib-šarri, the widow of another vassal (Zakura-abum of Zalluhan). The second marriage was a flop, with tragedies galore; see LAPO 18, nos. 1242-50, pp. 464-79 and the note of Michaël Guichard, La vaisselle de luxe des rois de Mari, Archives royales de Mari 31, Matériaux pour le Dictionnaire de Babylonien de Paris 2 (Paris, 2005), pp. 386-87.

21 This information is culled from a number of texts; see Guillaume Bardet, in G. Bardet et al., eds., Archives administratives de Mari 1, Archives royales de Mari 23 (Paris, 1984). The terms used in the documents are sometimes honorary (ummum, literally "mother"), sometimes evocative (tārītum, "nanny"), and sometimes descriptive (mušēniqtum, "wet nurse"). The practice is known to us from our earliest archives; see Marilyn Kelly-Buccellati, "Urkesh and the North: Recent Discoveries," in David I. Owen et al., eds., Studies and Excavations at Nuzi 11/1, SCCNH 15 (Bethesda, Maryland, 2005), pp. 33-34; Martha T. Roth, "Deborah, Rebekah's Nurse," in Israel Eph'al et al. eds., Hayim and Miriam Tadmor Volume, Eretz Israel 27 (Jerusalem, 2003), pp. 203*-7*. A very touching testimony on the roles of nannies is conveyed by ARM 26 298. An administrator tries to deflect blame for the sunstroke suffered by his new queen (Beltum, the Qatna princess mentioned above). Her nanny, he claims, did not have sense enough to warn her mistress against dancing in the palace's inner courtyard during the siesta hour.

${ }^{22}$ M. Bonechi and A. Catagnoti, "Compléments à la correspondance de Yaqqim-Addu, gouverneur de Saggarâtum," Florilegium Marianum 2 (1994): 63. 
her own acceptance of a new status, the attachment of nannies to her person, the merging of two families, the anxiety of the bride's family, the long trek back, and the preparation of a chamber for the new mistress of the house. With all this in mind, we return to the drama that unfolds in Genesis 24.

\section{The STORY ${ }^{23}$}

In plotting the story of Isaac's nuptials as it unfolds, some scholars have offered more elaborate analyses of the structure than others, promoting outlines that are prompted by differing goals. ${ }^{24}$ For my purposes, it suffices to break up the narratives into two major panels, the first gives a narrative of events (Gen. 24:1-27), and the second repeats this information from different perspectives (34-49).

\section{Panel A. Narrative of Events (24:1-27)}

THE SETTING

\section{a. Prologue (24:1)}

${ }^{1}$ Abraham was now old, advanced in years, the LORD having blessed Abraham in all things.

It is commonly noted that the opening (no less than the ending) of this narrative presumes and covers the imminent death of Abraham. ${ }^{25}$ When applied to Joshua, the formula "old, advanced in years" (Josh. 13:1 and 23:1) collates activities that are nearly synchronous, with his death not announced until later (Josh. 24:29). In reference to David (1 Kings 1:1), however, the same formula is only anticipatorily connected with an imminent death, requiring yet another formula to finally set it up (1 Kings 2:1, ויקרבו ימי־דוד למוזיד "David's death loomed"). In fact, the episodic style of the narratives that recount the life of Abraham is only tenuously attached to a biological clock; witness the ages in which Abraham and his spouse go through major moments of their lives. The same can be said of Isaac. Rebekah herself is famously unattached to chronology, except when her twenty-year barrenness (computed from 24:20 and 24:26, in reference to Isaac) is reported. In his opening, however, the narrator may be more interested in conveying the Lord's blessing, יהוה ברך את־אברהם בכל, because it concretizes the divine promise. This vocabulary (largely Deuteronomic) becomes crucial in the Servant's appeal for the bride.

23 Biblical citations are to verses in Genesis 24 but are fully displayed when not. Translations are adapted from TANAKH: The Holy Scriptures (New York, 1985).

24 See Aitken, "The Wooing of Rebekah," esp. pp. 4-7. The Documentary Hypothesis has complicated an exposition of the story's structure; see a review of the issues in Claus Westermann's Genesis 1236 (Minneapolis, 1985), pp. 383-84. As will be noted soon, extracting two sources from the story was largely argued on differences between the narrator's exposition of events and the servant's retelling of the same; see
Hermann Gunkel, Genesis, trans. Mark E. Biddle (1977; Macon, Georgia, 1997), pp. 241-48 and the vigorous critique by John van Seters, in Abraham in History and Tradition (New Haven, Conn., 1975), pp. 240-48.

${ }^{25}$ For this reason, a number of excellent commentators (among them Gunkel and Westermann) emend the ending at v. 67 to read "Isaac loved her, and thus found comfort after his *father's* death." The emendation is hardly supported textually, psychologically, or, as we shall see, narratologically. 


\section{b. The Oath $(24: 2-4)$}

${ }^{2}$ Abraham said to the senior servant of his household, who had charge of all that he owned, "Put your hand under my thigh ${ }^{3}$ and I will make you swear by the LORD, the God of heaven and the God of the earth, that you will not take a wife for my son from the daughters of the Canaanites among whom I dwell, ${ }^{4}$ but will go to the land of my birth and get a wife for my son Isaac."

The advanced age of Abraham excuses him from himself seeking a bride for Isaac. Equally relevant is the sentiment about not leaving the Promised Land that the narrator will soon develop. But we must also keep in mind that in previous narratives (Genesis 14, for example) Abraham has been treated as a ruler (the Greek of 23:6 has $\beta \alpha \sigma \imath \lambda \varepsilon \dot{v} \varsigma$ for "select of God"), and thus commissioning an emissary suits the long distance betrothal we have just described. ${ }^{26}$ The servant he selects is unnamed, but traditional commentators have not hesitated to call him Eliezer (from Gen. 15:2, where, however, he is not called a servant), at once giving him individuality but also creating for him an unflattering Midrashic life. ${ }^{27}$ Here, however, he is identified in two ways: he is זקן ביתו, literally "the eldest of [Abraham's] home," a phrase unique here, and המשל בכל-אשר-לו "who controls all that he owns." Aside from giving us a sense of this man's prominence, the two attributions work symbiotically: he is wise because he is old; he is important because he knows his master's world intimately. We cannot claim the same virtues for the two ambassadors who traipsed to Halab on behalf of Zimri-Lim, but we can say that the diviner Asqudum, who knew how to read omens, and the Kapellmeister Rišiya, who worked in the king's inner boudoir, were also picked because their master had deep confidence in their good sense.

The burden of the oath is to establish the ethnicity of the future bride. ${ }^{28}$ But beyond requiring that she cannot be a Canaanite, Abraham has only vague instruction on where to seek her. "You will go to the land of my birth" (אל־ארצי ואל־מולדתי תלך) could easily have sent the servant to Ur of the Chaldeans (Gen. 11:27-31), when Abraham certainly meant him to go to the Haran area. ${ }^{29}$ This lack of detail provokes the servant to inquire

${ }^{26}$ For reasons that differ from my exposition (and which I do not adopt) John van Seters claims that in Genesis 24 Abraham is treated as a king: Prologue to History: The Yahwist as Historian in Genesis (Louisville, Kentucky, 1992), p. 267. Robert Alter makes this prescient statement, ". . . the betrothal is expressed ceremoniously, as a formal treaty between two branches of the Nahor clan, and so the bestowal of gifts is specified here, and we are given the precise diplomatic language in which betrothal negotiations are carried out"; see his The Art of Biblical Narrative, p. 53.

27 For the sharply negative lore about the servant, see L. I. Rabinowitz, "The Study of a Midrash," Jewish Quarterly Review 58 (1967), pp. 145-50; Teugels, Bible and Midrash, pp. 171-81. In fact, in the midrashim no character from this story (including Isaac and Rebekah) fared well. Anonymity as a narrative strategy is not unknown in Scripture; see, among others, Judg. 19-20 (a Levite), 1 Kings 10 (Queen of Sheba), 1 Kings 13:110 (a man of God); Ruth 4:1 (Naomi's potential redeemer), 1 Chron. 11:15-19 (David's champions), and 2 Chron. 25:15 (an anonymous prophet).
28 There is much speculation on what specific gesture is intended here, at 24:9 and at Gen. 47:29. Some commentators treat the expression as a euphemism for cupping the genitals. In one of the wonderful Sumerian love poems, Inanna makes Dumuzi take an oath (lines 18-26), "My brother, I shall impose an oath on you, my brother of the beautiful eyes. You are to place your right hand on my genitals while your left hand rests on my head, bringing your mouth close to my mouth, and taking my lips in your mouth: thus you shall take an oath for me. This is the oath of women, my brother of the beautiful eyes"; cited from http://etcsl.orinst.ox.ac. uk/cgi_bin/etcsl.cgi?text=t.4.08.02\#. Passion may have overtaken reality here.

${ }^{29}$ In 11:28 the phrase ארץ מולדת seems to be a hendiadys and is equated with Ur of the Chaldeans. (We need not try to locate this area, whether in southern Iraq, Upper Syria, or closer to Anatolia; see the dictionaries and commentaries.) The Greek of 24:4 expands

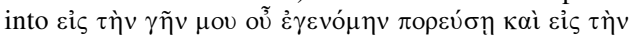

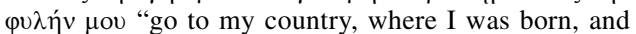
to my tribe." In 24:7, Abraham has added בית אבי "my 
further, but he will soon also develop his own interpretation of what Abraham wished him to do.

\section{c. The Restriction (24:5-9)}

${ }^{5}$ And the servant said to him, "What if the woman does not consent to follow me to this land, shall I then take your son back to the land from which you came?" 6 Abraham answered him, "On no account must you take my son back there! ${ }^{7}$ The LORD, the God of heaven, who took me from my father's house and from my native land, who promised me an oath, saying, 'I will assign this land to your offspring' - he will send his angel before you, and you will get a wife for my son from there. ${ }^{8}$ But if the woman does not consent to follow you, you shall then be clear of this oath to me; but do not take my son back there." ${ }^{9}$ So the servant put his hand under the thigh of his master Abraham and swore to him as bidden.

Facing the vague likelihood of success and the ambiguity of the mission, the servant guides Abraham into formulating a release clause, cleverly wondering whether Isaac can be taken to the bride's familiar surroundings. (We know, of course, that in interdynastic marriages such a trajectory is impossible for the groom.) From this exchange comes Abraham's certainty of providential guidance but also the amendment that the bride herself must be ready to come to Canaan. Abraham's instruction, however, remains imprecise and cryptic. When later the servant restates his master's directives (at 24:40), he dilates Abraham's words, adding "to make your errand successful." 30 This expansion of information needs notice, as it permits a better appreciation of the servant's frame of mind.

\section{DIVINE SELECTION}

\section{a. The Condition (24:10-14)}

${ }^{10}$ Then the servant took ten of his master's camels and set out, taking with him all the bounty of his master; and he made his way to Aram-naharaim, to the city of Nahor. ${ }^{11} \mathrm{He}$ made the camels kneel down by the well outside the city, at evening time, the time when women come out to draw water. ${ }^{12}$ And he said, "O LORD, God of my master Abraham, grant me good fortune this day, and deal graciously with my master Abraham: ${ }^{13}$ Here I stand by the spring as the daughters of the townsmen come out to draw water; ${ }^{14}$ let the maiden to whom I say, 'Please, lower your jar that I may drink,' and who replies, 'Drink, and I will also water your camels'-let her be the one whom you have decreed for your servant Isaac. Thereby I shall know that you have dealt graciously with my master."

The controlling language for his passage comes to us from two linked phrases in 24:12 that the servant utters when soliciting God's help. The second is fairly prosaic, עשהדיחסד עדם deal graciously with my master Abraham," as it draws on the divine promise to Abraham. But it does get repeated in this story: at 24:12 where it brackets the condition of the test, at 24:14 where the servant acknowledges the sign that God has sent him (see below),

father's home"; see below. Some argue that מולדת may mean "kindred," but such an understanding is contextual, for in other biblical contexts this word applies generally to an area that may include people of different affiliation or background (31:13; Jer. 22:10, 46:16;
Ezek. 23:15; Ruth 2:11).

${ }^{30}$ In the other biblical references to God sending angels (Exod. 20:23, 33:2, Num. 20:16, and Mal. 3:1) they are also assigned specific tasks. 
and at 24:49 where the capacity to benefit Abraham is tendered to Rebekah's family. It is the first of the two phrases, however, that generates the tension in the servant's dilemma. He has had precious little direction on how to accomplish his mission, so he needs prescience on how to act but also some help from above. The phrase הקרה־נא לפני היום, literally meaning "make it happen before me now," gives us access to his state of mind. With it, essentially the servant is asking God to further a predesired end, to ease his task but also to fulfill his oft-stated promise to his master. The same sense of providential control of a human-set goal occurs in Gen. 24:20 where "Esau" (Jacob in disguise) assures his father (blasphemously) that God has granted quick fortune in locating the prey destined for Isaac's meal. ${ }^{31}$

This program of setting goals for providential fulfillment is conveyed by the narrator's evocation of the servant's deeds and by the choice of vocabulary assigned to the servant himself. The details themselves play important roles in delivering this program, among them the nicely distributed appearance of camels in this story. In the recent past their mention in Genesis has come to be a test for imposing a date on the patriarchs' existence: if camels were not domesticated until the Iron Age, as some interpret the archaeological and textual evidence, then the activities of the patriarchs cannot be set earlier than that.$^{32}$ The argument is debatable and may even be specious, since the retelling of past behavior need not be historicizing or anthropological. The burden of vv. 10-11, however, is not to register history but to sharpen elements in the plot:

1. The number of camels (ten) may seem conventional, but it will enhance the starkness of the test that the servant will soon impose. One camel can drink up to 100 liters per session, requiring Rebekah to fill her single 15- to 20-liter jar half a dozen times. With ten camels to water, the poor girl will have made dozens of hauls by submitting to the test. That this chore might also inform us about the future bride's physical, mental, and social fitness has occurred to traditional commentators.

2. The reference to the servant loading "the bounty of his master" may accord with some reality-when he traveled far, Zimri-Lim always took along his treasured vessels, but it is meant to display better the wealth of the potential groom.

3. The silence about any personnel accompanying the servant on his voyage may accord with the reports in the Mari records cited above, but it also explains the oddity of a man depending on a single young woman to water his animals. In fact, when the servant's men finally make their appearance (24:32), they receive rather than give aid.

4. The notice about reaching the "city of Nahor," Nahor being Abraham's brother, opens a series of striking coincidences aiming at sharpening the role of divine providence. The

31 We have a differently constructed combination of goals and luck in Ruth 2:3, for which see my comments in Ruth: A New Translation, With a Philological Commentary and a Folkloristic-Formalist Interpretation, rev. ed. (1979; Sheffield, 1989), pp. 44-45.

32 Most Bible references reserve an entry for "camels," with The Anchor Bible Dictionary offering two, one under "Camels" and another under "Zoology, Equids." A recent camel-centered Iron Age dating is defended in Susanne Gillmayr-Bucher's “wehinneh gemallim ba'im," Zeitschrift für katholische Theologie 116 (1994): 421-26. In an early second-millennium poem, however, Dumuzi tastes the sweet milk of camels (http://www-etcsl.orient.ox.ac.uk/section4/tr40816.htm, Segment C, lines 18-27; see also Chicago Assyrian Dictionary I/J, s.v. ibilu). For interesting lore about the camel and its behavior, see Knut Schmidt-Nielsen, "The Psychology of the Camel," Scientific American 201/6, December 1959, pp. 140-51 and http://nabataea.net/ camel.html. 
narrator could have written "Haran," especially when the last reference to Abram in his native land has him set out from there (12:4-5). But Haran was a major town, with famous temples to the moon-god among others, and so harbored the broad ethnic mix. "The city of Nahor," however, alleviates somewhat our own (but not the servant's) anxiety about his chance of finding the right damsel.

5. Camels are normally made to kneel when taking or dropping passengers, but if they are loaded with goods, kneeling comes at the end of a journey when they can be relieved and then made to stand for the watering. ${ }^{33}$ The seemingly superfluous notice about where the servant parked his camels gives yet another indication that he was predisposed to look for the potential bride among the water-drawers. It is at this point that God has to take over responsibility for selecting Rebekah.

How God was maneuvered into solving the servant's problem has long been the subject of debates. Josephus makes the choice simply an answer to prayers (Ant. 16.2-3), with Rebekah standing out among the maidens by her piety and noble character. ${ }^{34}$ Commenting on 24:13, the Midrash Rabbah (Gen. 60:3) picked up cues from Talmudic lore to give this assessment: "Four asked improperly: three were granted their request in a fitting manner, and the fourth, in an unfitting manner. They are: Eliezer, Caleb, Saul, and Jephthah. Eliezer (said), 'so let it come to pass, that the damsel, etc.' - but it could have been a bondmaid! Yet God prepared Rebekah for him and granted his request in a fitting manner." ${ }^{35}$ In fact, this rabbinic material hardly makes a distinction among divinatory practices (not at stake in any of the examples), vows (Jephthah, Caleb, Saul), and simply tests of God's will or choices. Our example belongs to the last category, and its best analogues are found in diverse anecdotes about Gideon and God testing each other (the trial with the fleece, Judg. 6:36-40; the dream sent to the Amalekite, 7:9-15) or about Jonathan at the Philistine outpost (1 Sam. 14:4-14). Such tests depend on strict formulations, both of the condition and of the result, and while the manifestation of the result is mundane, the presumption is that there is divine control behind it. For this reason, much as it is ennobling to imagine that by his condition the servant is testing the virtue of the future wife (Sternberg calls it a "shrewd character test"), ${ }^{36}$ he could only be testing God's investment in Abraham's future.

The condition itself is made up of two parts: what he will ask (הטי־נא כדך ואששתה"Please,

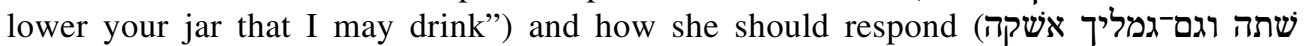
"Drink, and I will also water your camels"). Once they occur in their precise formulation and sequence, the consequence, God's choice, would be deemed imposed (לפתה הכחת you will have decreed her for your servant, for Isaac”).

\footnotetext{
33 Later, when the servant comes into his hosts' home, we are told that he ויפתח הגמלים, a phrase often rendered, "unpack" or "unload" the camels (24:32). The verb's basic sense, however, has to do with "freeing, letting loose."

34 See Thomas W. Franxman, Genesis and the Jewish Antiquities of Flavius Josephus, Biblica et Orientalia 35 (Rome, 1979), pp. 164-68.

35 The servant's formulation has prompted heated reactions from Maimonides, who strongly disapproved of it (Hilkhot Avodah Zarah, 11.4), and from his con-
}

temporary Rabad (Abraham b. David of Posquières, fl. late twelfth century). Rabad would not condemn how a venerated patriarch (or his servant) found a wife, relying on Babylonian Talmud's Hullin 95b for his opinion.

36 Sternberg, Poetics, p. 137.

37 The hiphil of the verb יכה has a strong legal sense, something like "adjudge," not at all equivalent to "assign" or "appoint," which are found in many translations and created in dictionaries for just this context. 


\section{b. The Uncertainty (24:15-20)}

${ }^{15} \mathrm{He}$ had scarcely finished speaking when Rebekah, who was born to Bethuel, the son of Milcah the wife of Abraham's brother Nahor, came out with her jar on her shoulder. ${ }^{16}$ The maiden was very beautiful, a virgin whom no man had known. She went down to the spring, filled her jar, and came up. ${ }^{17}$ The servant ran toward her and said, "Please, let me sip a little water from your jar." 18“"Drink, my lord," she said, and she quickly lowered her jar upon her hand and let him drink. ${ }^{19}$ When she had let him drink his fill, she said, "I will also draw for your camels, until they finish drinking." ${ }^{20}$ Quickly emptying her jar into the trough, she ran back to the well to draw more water; indeed she drew for all his camels.

God, it seems, is already ahead of the servant, for even as the latter is shaping his test, God was directing the young woman's appearance on the scene. Such coincidences are fodder for folktales, of course, as hardly any person has to wait long before the appearance of the target person (Jacob and Rachel, Moses and Zipporah, Jonah and his Tarshish ship, Ruth and Boaz, Boaz and Mr. So-and-So, etc.). What is surprising in the launching of the test is that neither the servant nor Rebekah will accurately follow the libretto.

As set by the servant, the condition involved a נערה (defective for, a word that, unfortunately, is broad enough in Hebrew to include virgins (Deut. 22:23) and prostitutes (Amos 2:7), concubines (Judg. 19:3) and widows with years of marriage (Ruth). It is now generally acknowledged that Hebrew בתולה only occasionally matches our notion of a "virgin" (a virgo intacta); rather, it refers to a young women who has not given birth. ${ }^{38}$ For precisely these ambiguities, and given the stake in the purity of the ancestors' bloodline, at 24:16 the narrator felt it was appropriate to insert a comment on Rebekah's lack of sexual experience, an occasion for many commentators to (unnecessarily) wax eloquent on the young woman's virtues. ${ }^{39}$ That the narrator also compromises suspense by revealing Rebekah's pedigree may surprise us, but for one keeping up with the narratives of the patriarchs, it had been disclosed long ago, at 22:23, when the fates of Isaac and Rebekah seem to lock already. ${ }^{40}$

Biblical convention has it that people properly display eagerness and politeness by "running" to meet someone, with many examples, especially in Genesis and Samuel. ${ }^{41}$ We will have plenty of running about in this story, the first among them involving the servant as he addresses Rebekah. But as Rebekah hears it, the words of the servant's request, הגמיאיני נא מעט־מים מכדך "let me sip a little water from your jar," are not at all

\footnotetext{
38 G. J. Wenham, "Betulah, 'A Girl of Marriageable Age," Vetus Testamentum 22 (1972): 326-48. The same can be said about Akkadian batultum (mí.kal.tur), Ugaritic btlt, and other terms (such as עלמה) that describe a young woman.

39 Rabbinic exegesis wallowed in sexual speculation when establishing Rebekah's perfection; see M. J. H. M. Poorthuis, "Rebekah as a Virgin on her Way to Marriage: A Study in Midrash," Journal for the Study of Judaism 29 (1998): 438-62. Teugels, Bible and Midrash, pp. 193-211. On the age of Rebekah, see Rabinowitz, "Study of Midrash," pp. 150-52, and Teugels, Bible and Midrash, pp. 213-26. Traditions have her as either three ([sic], depending on her mention in 22:23, allegedly after the Akedah) or
}

fourteen; see Teugels once more, pp. 213-23.

40 See Nahum M. Sarna, "The Anticipatory Use of Information," reprinted in his Studies in Biblical Interpretation (Philadelphia, 2000), pp. 214-17.

${ }^{41}$ It is said of: Abraham greeting visitors (actually divine powers) at 18:7; Laban greeting the servant at 24:29 and Jacob at 29:13; Esau to embrace Jacob at $33: 14$. Women generally run to report to family or to husbands: Rebekah at 24:28, Rachel at 29:12. The verb רוץ may be adverbially attached to another מהר "to hurry," to convey the meaning "run in haste," as with Samson's mother to her husband (Judg. 13:10); but even when the two verbs control different objects, as in our 24:20, the sense is that of dealing with matters promptly. 
what he had originally formulated in his appeal to God, הטי־נא כדך ואשתה "Please, lower your jar that I may drink." The verb he uses this time, in fact, is rather odd; in the only other use of it (piel rather than hiphil), it is applied to a horse metaphorically swallowing the ground (Job 39:24; it is occasionally conjectured in Ezek. 23:34). ${ }^{42}$

Rebekah's response is what the servant hoped for but not quite. The test was to have her answer, שתה וגם-גמליך אשקה "Drink, and I will also water your camels." Rebekah, however, is much more expansive, using many more words than expected, perhaps even nobly promising beyond what the servant expected for his camels. But what may have compromised the test was her action: there was a time lapse and a chain of actions between her "Drink, my lord," and "I will also draw for your camels, until they finish drinking." The servant needed to assess this discrepancy from the script.

\section{c. The Confirmation (24:21-27)}

${ }^{21}$ The man, meanwhile, stood gazing at her, silently wondering whether the LORD had made his errand successful or not. ${ }^{22}$ When the camels had finished drinking, the man took a gold nose-ring weighing a half-shekel, and two gold bands for her arms, ten shekels in weight. ${ }^{23}$ "Please tell me," he said, "Whose daughter are you? Is there room in your father's house for us to spend the night?" ${ }^{24}$ She replied, "I am the daughter of Bethuel the son of Milcah, whom she bore to Nahor." ${ }^{25}$ And she went on, "There is plenty of straw and feed at home, and also room to spend the night." ${ }^{26}$ The man bowed low in homage to the LORD ${ }^{27}$ and said, "Blessed be the LORD, the God of my master Abraham, who has not withheld his steadfast faithfulness from my master, for I have been guided on my errand by the LORD, to the house of my master's kinsmen."

The literature is full of comments on the meaning of the opening line, as it contains some difficult language. ${ }^{43}$ For the servant, however, the problem was in deciding whether or not his test has concluded happily or not. Had the young woman given him the exact answer he framed, his test would have proven definitely conclusive, even before she completed her proposed watering. He now had plenty of time to ponder the matter; for her chore, as noted above, must certainly have occupied her for hours! Given the quandary, the servant decides on sharpening the test, giving God another chance to clarify his will. ${ }^{44}$ Before

42 It is hard to judge whether or not the consonants גמא acamel."

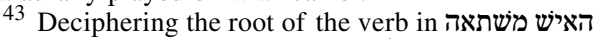
לה have led to many conjectures, often dependent on the versions; see Robert Gordis, "A Note on Gen. 24:21," American Journal of Semitic Languages and Literature 51 (1935): 191-92. The meaning of the sentence, however, is fairly clear.

${ }^{44}$ That the sequence for the gift-giving is reversed in the servant's account (at 24:47) has been noticed by most commentators. But aside from harmonizing them or indicating primacy of (or preference for) one over the other, few have tried to explain the import of this phenomenon; see Teugels, Bible and Midrash (pp. 8090) for a nice exposition of the different suggestions. Many in fact (including the great Ibn Ezra) have preferred the second version of events of 24:47. Rashi (q.v. at 24;23) notes, " 'He asked her, whose daughter are you?': He posed the question to her because he was confident of Abraham's reassurance that God would make his journey successful." See also 24:47, where Rashi reasons that the switch saved the servant from explaining the giving of gifts to an as yet unknown young woman. Among the few contemporary scholars to find plot significance in the reversal, however, is Andrew Schein in "The Test of Rebecca," Tradition 32 (1997): 28-33. For him, the servant concocted the test, in full hearing of others, not to locate a bride, but to fabricate a divine approval for the match so that the marriage proposal be accepted. The servant had done his research, knew that the young woman was just perfect, and recognized her instantly from the description provided him. He gains Rebekah's approval by offering her gifts and spends little time with the family once they accepted the match lest they change their mind. Obviously there is a novella here, but proper exegesis can hardly hinge on episodes or scenes that are not delivered by the text under inspection. 
learning the identity of Rebekah, he decides on her as the potential bride by offering her rich gifts. Scholarly suggestions to the contrary, the objects he gives her (the gold nose-ring and bracelets) are hardly payment for a kind act-an object less precious than gold might have more than fulfilled such a goal. ${ }^{45}$ And they are certainly not meant to secure Rebekah's goodwill, although they might have had such an effect. In fact, the items he showers on the young woman find their equivalence in the bridal gifts God (allegorically) gives his (perverse) wife (Ezek. 16:11-12) and the formulaic language is closest to the gift list of Numbers $7 .{ }^{46}$

What is at stake here is not so much a new test but a search for confirmation of a previous test. The proof of the choice would come from the young woman, as she declares herself a kin of the future groom. In the ancient Near East, it was the practice in matters of discovering the will of the gods to seek affirmation, even when an answer was straightforward. From Mesopotamia, we know of such measures best in omen-taking, when repeating the inquiry, reformulating the question, or assigning the search simultaneously to diverse diviners improved the prospects for establishing reliability through multiple agreements. ${ }^{47}$ In Mari, there was also the appeal of establishing validity by diversifying the routes to the same truth: omen taking, dreams, and diverse forms of prophecy could combine to deliver corroboration..$^{48}$ In Israel, likewise, the urim and thummim were recast even when the initial answer was as clear as a bell (for example, at 1 Sam. 23:1-14). Later, when prophecy became a major mode for ascertaining divine intent, kings of Israel kept a large number of prophets around, so acquiring better control through harmony or contrast among pronouncements. ${ }^{49}$

The two questions the servant asks the young women are themselves part of the test for confirmation. We notice first that he does not ask her name. It is far-fetched to imagine that the convention obtaining in Mari, to name the bride only after her troth is announced, is at work here. Rather, the servant is interested here in a detail that is much more precious to him. He needs to know her pedigree for certain ("whose daughter are you?"), but he must

45 Skinner, Genesis, p. 343, scolds Gunkel for judging them as bridal gifts (Genesis, pp. 252-53). Westermann, Genesis, p. 387: "This is nothing other than his joyful reactions to the girl's obliging readiness to refresh him and his animals (not some sort of bride price!)."

46 We note the precision with which similar gifts are recorded in a Mari text (ARM 26 11) cited above. Similar gifts are given with even fuller detail in the terhatum and nidittum lists from the same archives. The few lines still preserved from the terhatum inventory of Šiptu (ARM 25 616, reedited by Durand ARM 26/1, pp. 101-2), mention jewelry, precious vessels, clothing, and leather goods. Because the nidittum accompanied a daughter into a new home, it also included furniture, kitchen tools, and servants (including female scribes). See, for example, the dowry accompanying Princess Šimatum; ARM 25 603, with slight expansion in ARM 22322.

47 See the excellent remarks of J.-M. Durand in ARM 26/1, pp. 46-51. A useful overview of divination and oracular techniques across ancient cultures, penned by diverse authors (pp. 370-91) is in Sarah Iles Johnston, ed., Religions of the Ancient World: A Guide (Cambridge, Mass., 2004).

48 For example, Šiptu writes her husband (ARM 26 212:1'-16' = LAPO 18 1146):

Regarding matters about Babylon, I gave (men and women) signs to drink and made enquiry. This man [Hammurabi of Babylon] plots many things against this land, but he will not prevail. My lord will see what God will do to this man. You will capture him and stand over him. His days are numbered; he will not live long. My lord should know this. Even before receiving the message of Ili-haznaya [a prophet] that (the goddess) Annunitum sent through him-five days ago in factI myself posed (a similar) query. The message that Annunitum sent you and the information I obtained through inquiry are one and the same.

49 On these matters, see my forthcoming paper, "Oracle Inquiries in Judges," a contribution to a Festschrift. 
also (obliquely) ascertain whether or not she is married ("Is there room in your father's house for us to spend the night?"). Were she already the wife of another, she would have offered the hospitality of her husband's family rather than her own. ${ }^{50}$ With her twofold reply the young Rebekah is reassuring: she is of the right lineage ("I am the daughter of Bethuel the son of Milcah, whom she bore to Nahor"), and she is unmarried ("There is plenty of straw and feed at home and also room to spend the night"). The servant can now acknowledge that the test and its confirmation have come to a happy ending. The elaborate curtsy does just that. As elsewhere in Scripture, it signals to God that his message has indeed been received and correctly deciphered. ${ }^{51}$ A prayer of thanks follows, fully praising God for his solicitude and guidance. All should be well, but Abraham had imposed another stipulation: the young woman must agree to leave her own homeland. How to negotiate this obligation is the servant's next challenge.

\section{TRANSITION}

\section{The Welcome (24:28-33)}

${ }^{28}$ The maiden ran and told all this to her mother's household. ${ }^{29}$ Now Rebekah had a brother whose name was Laban. Laban ran out to the man at the spring- 30 when he saw the nose-ring and the bands on his sister's arms, and when he heard his sister Rebekah say, "Thus the man spoke to me." He went up to the man, who was still standing beside the camels at the spring. ${ }^{31}$ "Come in, O blessed of the LORD," he said, "why do you remain outside, when I have made ready the house and a place for the camels?" ${ }^{32}$ So the man entered the house and unloaded the camels. [Laban] gave the camels straw and feed as well as water to bathe his feet and those of the men with him. ${ }^{33}$ But when food was set before him, he said, "I will not eat until I have told my tale." He said, "Speak, then."

The young woman runs to her mother's house, that is, to the women's quarters, but how she shared the news with other members of the family is not clearly charted. ${ }^{52}$ The narrator is eager to introduce Laban, one of the more colorful, if also among the most manipulative, characters in Genesis. Perhaps Laban had run to the servant even as the young woman was still in her mother's house? There is some narrative regression to give Laban a glimpse of the gifts with which his sister was laden and to hear her report (once more?) on her interview with the servant. (What possibly could she report besides his request for water, his question about her identity, and his search for hospitality?) We are soon back to the camels and the invitation to the servant. Laban's initial greeting is psychologically crucial. Addressing the

\footnotetext{
50 Josephus's servant is blunt enough to ascertain her marital status by wishing Rebekah a happy marriage.

51 The vocabulary of this gesture may differ somewhat, but it includes verbs (most often hishtafel of חוה) for "bowing low (in homage, often adverbially with קדד (קדling on one's face," "falling in prostration to the ground," and the like: Exod. 34:8 (Moses acknowledges God's attributes, but then invokes them for mercy); Num. 22:31 (Balaam becomes conscious of the angel's presence); 1 Sam. 28:14 (Saul recognizes the presence of Samuel's ghost); Judg. 7:15 (Gideon bows low when he hears a dream told and interpreted); Josh. 5:14 (Joshua acknowledges the presence of God).
}

Groups can also display the same reaction, as in Exod. 12:27 (Israel accepts the Passover sacrifice as a sign).

52 Sternberg is quite good-perhaps too facile-at solving the difficulty through multiple perspectives and by positing a "sequential shift in portrayal," Poetics, pp. 143-45. Carol Meyers explores the implication of בית where the story has a surfeit of בית "To Her Mother's House': Considering a Counterpart to the Israelite Bêt 'ab,' in D. Jobling et al., eds., The Bible and the Politics of Exegesis: Essays in Honor of Norman K. Gottwald on His Sixty-fifth Birthday (Cleveland, 1991), pp. 39-51. 
servant as ברוך יהוה "blessed of the Lord" is significant for it conveyed to him that YHWH, Abraham's God and the arbitrator of the test, is also venerated by this particular family. Given the servant's plan of action, this cannot be bad at all, possibly for him yet another confirmation that his strategy has been correct. ${ }^{53}$ What follows is fairly conventional but also symbolic for the future merging of families. There is the feeding of the animals and the washing the feet of the servant and of all his men (who famously become visible here). ${ }^{54}$ There is also the invitation to a meal, refused by the servant who is eager to tell his story. (See Tob. 7:11, likely dependent on our passage. $)^{55}$

\section{Panel B. The Servant's Tale (24:34-49)}

Until recently, commentators were wont to attribute the servant's expansive retelling to Oriental prolixity or to "epic peculiarity," even when they duly noted differences from the narrator's original recording of events. ${ }^{56}$ Ironically enough, now that we find a fair amount of rigorous repetition in some ancient literature (Sumerian and Ugaritic poetry can repeat great numbers of lines), such recapitulations can be mined for clues on the narrator's art as well as for insight on how characters fulfill their roles. In fact, few are the present-day contributions that do not recognize narrative art or plot design behind the differences. ${ }^{57}$ Still, to sharpen the differences I set the servant's retelling of events (left column) in parallel with the narrator's original presentation (right column). I have highlighted alterations in formulation with bold italics.

\section{SERVANT's RETELLING NARRATIVE}

(ADDITIONS OR CHANGES: IN BOLD ITALICS)

\section{a. Prologue (24:34-36)}

34“I am Abraham's servant," he began. ${ }^{35}$ "The LORD has greatly blessed my master, and he has become rich: he has given him sheep and cattle, silver and gold, male and female slaves,

53 The phrase is also known from Gen. 26:29 where, addressing Isaac, Abimelech of Gerar recognizes him as a particularly fortunate person (see Isa. 65:23, plural). Laban could have invoked a less personal divine name, such as בעל or בלהים; the last in fact occurs in the Phoenician (debated) phrase hbrk $b^{\complement} l$ "the blessed of Baal": attached to Azatiwada (cited from Context of Scripture, 2, 149:i1) and to Urikki (cited from R. Tekoğlu and A. Lemaire, "La bilingue royale louvitephénicienne de Çineköy," Comptes rendus de l'Académie des inscriptions et belles-lettres, année 2000 [Paris, 2002], p. 994). Gunkel (Genesis, p. 253) ascribes the mention of Yahweh to the "legend's naiveté."

54 Giving water to wash the feet is an invitation for guests to relax (2 Sam. 11:8; Gen. 43:24; Judg. 19:21) and differs from its cultic (Exod. 30:19), metaphorical (Cant. 5:3), or ritual (John 13:1-20) equivalents. See the Egyptian New Kingdom tale of The Fated [or
${ }^{1}$ Abraham was now old, advanced in years, and the LORD has blessed Abraham in all things.

Doomed] Prince, where the hero is treated similarly on reaching Naharina (more or less Aram Naharaim!), in E. Wente's translation for W. K. Simpson et al., eds., The Literature of Ancient Egypt (New Haven, Conn., 1972), p. 87.

55 For comparisons between Tobit and Genesis 24, see P. Deselaers, Das Buch Tobit: Studien zu seiner Entstehung, Komposition und Theologie, OBO 43 (Fribourg and Göttingen, 1982), pp. 292-303. Josephus simply lets the servant sup before retelling events to Rebekah's mother (Ant. 16.3).

56 Driver, Genesis, p. 235.

57 See E. J. van Wolde, "Telling and Retelling: The Words of the Servant in Genesis 24," in Johannes C. de Moor, ed., Synchronic or Diachronic: A Debate on Method in Old Testament Exegesis (Leiden, 1995), pp. 227-44. 
camels and asses. ${ }^{36}$ And Sarah, my master's wife, bore my master a son in her old age, and he has assigned to him everything he owns.

The servant needed to introduce himself to the family, and he begins by identifying his master and his wife, interestingly enough using the names they acquired after they left Haran. In updating the family on his master's good fortune in Canaan, he naturally emphasizes two matters that serve to confirm the power of Abraham's god: his master's wealth and the heir produced by his mistress. To emphasize how precious the child was to his parents, he adds, "in her old age." (But why not "in his old age," surely another sign of blessing?). Isaac remains nameless throughout the servant's presentation, an observation that takes us back to the treatment of Šiptu's name in the Mari dossier. One tidbit seems to be the servant's invention: in the scheme of narratives about Abraham, we do not get to know of his decision to "will all that he owns to Isaac" until later (25:5). Biblical plotlines do not always obey chronology, but in light of how Asqudum, Zimri-Lim's diplomat, handled an issue that he may not have anticipated (see above, comments to ARM 26 13), we might imagine the servant to have improvised here as well. ${ }^{58}$ It was important for the family to know that their daughter's prospective conjugal ties to someone far away will not fall short of the happiness and security she might have had by marrying locally.

\section{b-c. The Oath and Its Restriction (24:34-41)}

${ }^{37}$ Now my master made me swear, saying, 'You shall not get a wife for my son from the daughters of the Canaanites in whose land I dwell, ${ }^{38}$ but you shall go to my father's house, to my kindred, and get a wife for my son.'

${ }^{39}$ And I said to my master, 'What if the woman does not follow me?' ${ }^{40} \mathrm{He}$ replied to me, 'The LORD, whose ways I have followed, will send his angel with you and make your errand successful; and you will get a wife for my son from my kindred, from my father's house. ${ }^{41}$ Thus only shall you be freed from my adjuration: if, when you come to my kindred, they refuse you-only then shall you be freed from my adjuration.'
${ }^{2}$ And Abraham said to the senior servant of his household, who had charge of all that he owned, "Put your hand under my thigh ${ }^{3}$ and I will make you swear by the LORD, the God of heaven and the God of the earth, that you will not take a wife for my son from the daughters of the Canaanites among whom I dwell, ${ }^{4}$ but will go to the land of my birth and get a wife for my son Isaac."

${ }^{5}$ And the servant said to him, "What if the woman does not consent to follow me to this land, shall I then take your son back to the land from which you came?" "Abraham answered him, "On no account must you take my son back there! ${ }^{7}$ The LORD, the God of heaven, who took me from my father's house and from my native land, who promised me an oath, saying, 'I will assign this land to your offspring'- $-\mathrm{He}$ will send his angel before you, and you will get a wife for my son from there. ${ }^{8}$ And if the woman does not consent to follow you, you shall then be clear of this oath to me, but do not take my son back there."

It is best to consider the next two segments together, for they reveal the servant's fine sense of the situation. As we saw above, Abraham had spoken of the servant going to

58 Sternberg, Poetics, p. 146, "The man's art lies
not so much in the slight stretching of the facts as in their thorough insinuation." In fact, it lies in both, as we shall see. 
"the land of my birth" (24:4) and upon prodding had made a slight change (24:7). There, Abraham did add מבית אבית "from my father's house" to a hendiadys version of what he had earlier used, but the allusion is negative, giving God credit for breaking him away from that unit. ${ }^{59}$ So, while the servant did feel directed to the Haran area, the message he bore was hardly conducive to success. In retelling his experience, the servant did not need to describe the process by which he took the oath ("Put your hand under my thigh ..."), but it was necessary for him to alter his master's instructions. First and most obvious, he removed any allusion to restricting Isaac to the Promised Land (at 24:3 and 8). He could do no less if he wished not to insult hosts who, after all, had no qualms about remaining in Haran. Also intrusive is his systematic alteration of the vocabulary that Abraham had used when referring to his former land. Within a few sentences (24:38-41), the servant משפחה משakes repeated and positive references to בית אב (extended) family" and to the

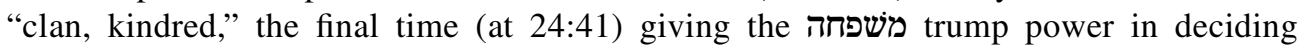
whether to approve of the match or not. This last touch may be the most significant change to affect the plot, for in response to the servant's own inquiry (24:5), Abraham had relieved him from the oath only "if the woman does not consent to follow you" (24:8). The servant may be incredibly diplomatic, but he has also created a problem for himself in that he remains under oath until by her consent Rebekah—not the family_frees him.

DIVINE SELECTION

$a-b$. The Condition and Its Fulfilment (24:42-48)

42" I came today to the spring, and I said, $\mathrm{O}$ LORD, God of my master Abraham, if you would indeed grant success to the errand on which I am engaged! ${ }^{43}$ As I stand by the spring of water, let the young woman who comes out to draw and to whom I say, 'Please, let me drink a little water from your jar', 44 and who answers, 'You may drink, and I will also draw for your camels'let her be the wife whom the LORD has decreed for my master's son'.

59 According to Josh. 7:16-18, the בית אב is the smallest of Israel's kinship units beyond the nucleus family. The term refers to an extended family that issues from a (living) ancestor, in this case Terah, who fathered Abraham and Nahor. That same Joshua context gives us the two other units in ascending scale: the משפחה (awkwardly "clan," more generally, "kindred")
${ }^{10}$ Then the servant took ten of his master's camels and set out, taking with him all the bounty of his master, and he made his way to Aram-naharaim, to the city of Nahor. ${ }^{11}$ He made the camels kneel down by the well outside the city, at evening time, the time when women come out to draw water. ${ }^{12}$ And he said, "O LORD, God of my master Abraham, grant me good fortune this day, and deal graciously with my master Abraham; ${ }^{13}$ here I stand by the spring as the daughters of the townsmen come out to draw water; ${ }^{14}$ let the maiden to whom I say, 'Please, lower your jar that I may drink,' and who replies, 'Drink, and I will also water your camels'-let her be the one whom You have decreed for Your servant Isaac. Thereby shall I know that You have dealt graciously with my master."

and שבט "tribe." For an archaeological, anthropological, and demographic evaluation of these and other terms, see J. David Schloen, The House of the Father as Fact and Symbol: Patrimonialism in Ugarit and the Ancient Near East, Studies in the Archaeology and History of the Levant 2 (Winona Lake, Indiana, 2001), pp. 150-55. 
${ }^{45}$ I had scarcely finished praying in my heart, when Rebekah came out with her jar on her shoulder and went down to the spring and drew.

And I said to her, 'Please give me a drink'. ${ }^{46}$ She quickly lowered her jar and said, 'Drink, and I will also water your camels'. So I drank, and she also watered the camels.

${ }^{47}$ I inquired of her, 'Whose daughter are you?' And she said, 'The daughter of Bethuel, son of Nahor, whom Milcah bore to him'. And I put the ring on her nose and the bands on her arms. ${ }^{48}$ Then I bowed low in homage to the LORD and blessed the LORD, the God of my master Abraham, who led me on the right way to get the daughter of my master's brother for his son.
${ }^{15} \mathrm{He}$ had scarcely finished speaking, when Rebekah, who was born to Bethuel, the son of Milcah the wife of Abraham's brother Nahor, came out with her jar on her shoulder. ${ }^{16}$ The maiden was very beautiful, a virgin whom no man had known. She went down to the spring, filled her jar, and came up. ${ }^{17}$ The servant ran toward her and said, "Please, let me sip a little water from your jar." 18“"Drink, my lord," she said, and she quickly lowered her jar upon her hand and let him drink. ${ }^{19}$ When she had let him drink his fill, she said, "I will also draw for your camels, until they finish drinking." ${ }^{20}$ Quickly emptying her jar into the trough, she ran back to the well to draw, and she drew for all his camels. ${ }^{21}$ The man, meanwhile, stood gazing at her, silently wondering whether the LORD had made his errand successful or not. ${ }^{22}$ When the camels had finished drinking, the man took a gold nose-ring weighing a half-shekel, and two gold bands for her arms, ten shekels in weight. 23،"Pray tell me," he said, "whose daughter are you? Is there room in your father's house for us to spend the night?" ${ }^{24}$ She replied, "I am the daughter of Bethuel the son of Milcah, whom she bore to Nahor." ${ }^{25}$ And she went on, "There is plenty of straw and feed at home, and also room to spend the night." ${ }^{26}$ The man bowed low in homage to the LORD ${ }^{27}$ and said, "Blessed be the LORD, the God of my master Abraham, who has not withheld His steadfast faithfulness from my master. For I have been guided on my errand by the LORD, to the house of my master's kinsmen."

The language for the test differs only lightly in its two formulations. Curiously, the narrator crisscrosses the servant's phrasings, setting up brackets in which crucial language in verse 14 parallels what is found in 46, and what is found in 18-19 is placed in parallel with material in 44 . There is another touch that I also attribute to the narrator without my capacity to explain it adequately: in talking to the family, the servant cites Rebekah by name when none of his previous dealings had brought him this information. We must attribute to the servant, however, the omission to recall raising the issue of hospitality for, as we saw above, its goal was to ascertain her marital status. Whatever their motivations, the crisscross arrangement and the insertion of Rebekah's name do not have the same plot consequence as the servant's obvious erasure of the doubts that he had displayed earlier when Rebekah's answer seemed to him equivocal. At that time he forced a divine decision by selecting the bride before uncovering her lineage. With Rebekah's family as his audience, there can only be certainty about the working of God's control. For this reason, all details about a second test to prove the validity of the first are removed and only one argument is made: once the young woman announced her name and gave her pedigree, God's will was done and, by beginning to 
shower gifts on the destined bride right then, the servant was merely acknowledging it. ${ }^{60}$ Justified in this particular manner, why Rebekah returned bejeweled from the well is not so much because he selected her as a bride for his wealthy master's only heir, but because he served as Heaven's pawn in fulfilling Rebekah's destiny. It was up to the family now to facilitate this development.

\section{d. The Request (24:49)}

${ }^{49}$ And now, if you mean to treat my master with true kindness, tell me; and if not, tell me also, that I may turn to the right or to the left.

This is an ultimatum but really also a challenge for the family of the bride to play the clinching role in a drama staged from heaven. It would be doing so, however, with consequences that are earthly, in fact advancing the cause of family solidarity. But the servant is bluffing. Could he back away from God's choice? Could he improve on divine providence by turning "right or left" (a merismus, conveying "somewhere else")?

\section{RESUMPTION OF NARRATIVE (24:50-61)}

\section{a. The Will of God (24:50-54a)}

${ }^{50}$ Then Laban and Bethuel answered, "The matter has been decreed by the LORD; we cannot speak to you bad or good. ${ }^{51}$ Here is Rebekah; take her and go, and let her be a wife to your master's son, as the LORD has spoken." ${ }^{52}$ When Abraham's servant heard their words, he bowed to the ground before the LORD. ${ }^{53}$ The servant brought out objects of silver and gold, and garments, and gave them to Rebekah, and he gave presents to her brother and to her mother. ${ }^{54 a}$ Then he and the men with him ate and drank, and they spent the night.

In rehearsing before his hosts the aim of his mission, the servant had wisely split his challenge: he would first get the family to agree to the betrothal before seeking the bride's own concurrence. Skillfully, the servant accentuates his master's wealth, sharpens the role of God in the selection of Rebekah, and, most importantly, gives the family power of decision. There is a major issue about the peek-a-boo role of Bethuel, Rebekah's father, whose active presence is limited to this verse. Josephus simply has him dead, giving the mother a major role. The rabbis give diverse scenarios suggesting his (deserved) murder. Luckily, the matter is not major for us. Between the declaration of the men around Rebekah in which they agree to a choice guided by the God of Abraham and the handing out of gifts to each and all, there is once again a public display of the servant's recognition of God's control. In answer, the men use a merismus, "bad or good" (in Hebrew often in reverse order), to convey the meaning "anything at all," but they may be countering the servant's phrase-making. The round of gifts itself is interesting. Given its narrative context, it may blend diverse discrete acts but seems nothing like the mohar that in Hebrew preexilic contexts serves to compensate parents for the loss of their daughter (Gen. 34:12; Exod. 22:16;

60 The servant attributes to Rebekah a male-centered lineage $(24: 47$ ". . . she [replied], 'The daughter of Bethuel, son of Nahor, whom Milcah bore to him" ") when in fact she had given prominence to her grand- mother (24:24 “. . . She replied, 'I am the daughter of Bethuel the son of Milcah, whom she bore to Nahor"'). A nice touch. 
1 Sam. 18:25). Unlike the sequence in recording the biblum to Yarim-Lim, Gašera, and then Šiptu (see ARM 2611 above), however, here pride of attention is given Rebekah, who, as did Šiptu, receives precious ornaments and clothing. Laban and his mother receive unspecified valuables. The distribution arrangement may not follow expected protocol, but it serves to keep the focus on Rebekah. With the family's agreement and the distribution of gifts, the matter may have ended here, were it not for the additional stipulation that Abraham added to the servant's charge: the young woman, not her parents, must be ready to leave her home. As the guests and their hosts have their communal meal (normally a sign of finality), the story moves to the resolution. ${ }^{61}$

\section{b. Rebekah's Choice (24:54b-58)}

${ }^{54 b}$ When they arose the next morning, he said, "Give me leave to go to my master." ${ }^{55}$ But her brother and her mother said, "Let the maiden remain with us some ten days; then you may go." ${ }^{56} \mathrm{He}$ said to them, "Do not delay me, now that the LORD has made my errand successful. Give me leave that I may go to my master." ${ }^{57}$ And they said, "Let us call the maiden and ask for her reply." ${ }^{58}$ They called Rebekah and said to her, "Will you go with this man?" And she said, "I will."

The servant's leave-taking is abrupt, but he had not come such a distance just to schmooze. (On completion of their mission, Rišiya and Asqudum displayed similar interest in a prompt departure; see ARM 26 11.) There is, however, the matter of preparing the bride, emotionally no less than materially, for a departure to a distant land. ${ }^{62}$ How long the requested interval is debated, the phrase ימים או עשור being imprecise. Some traditional commentators, Rashi among them, suggest up to a year, surely a stretch in all senses. ${ }^{63}$ Once more, the servant invokes Higher Powers, suggesting that the test he had described was not just to identify the bride but to get her to her groom. What is remarkably here is that the family seems to pull back from its earlier statement, when they urged the servant to "take [Rebekah] and go, and let her be a wife to your master's son, as the LORD has spoken." They do not ask, "Are you ready to go with this man now?" but, "Are you ready to go at all with the man?"64 Are they reneging by making the whole matter depend on the say of a young, hardly experienced woman? Or is the family merely bluffing, browbeating the servant to agree to the surcease he had just refused? Whatever the family's motivation, the servant does not flinch; once more he leaves it to God to guide what heaven has willed. This query introduces the last and, given Abraham's initial charge at 24:8 ("If the woman does not consent to follow you, you shall then be clear of this oath to me"), potentially the most crucial test in

61 Banquets are normally signs of finality: hosted by the bride's family (Gen. 29:22, Tob. 8:19 [21]) or by the groom's (Judg. 14:10; Matt. 22:4; 2 Esd. 9:47).

62 In the Mari records, when married princesses are summoned to their homeland it is usually a sign of a difficult or a failed marriage. This includes the case of Beltum, neglected wife of King Yasmah-Addu (ARM 251 = LAPO 17453 , p. 26) and of Kirum, divorced wife of Haya-Sumu, Zimri-Lim's vassal, who nevertheless seems to get stuck in her unhappy home; slightly different assessments of the dossier are found in Durand, LAPO 18, pp. 427-45, and in Heimpel, Letters to the
King of Mari, pp. 80-83. LAPO 18, no. 1230 (= ARM 1033 ), pp. $444-45$ is a searing first-person account of Kirum's divorce procedure.

${ }^{63}$ Elsewhere (at 29:24), Jacob waited a full week between spouses, but the number seems controlled by the seven years he worked to acquire each. Tobiah and Sarah leave for home after a fortnight of betrothal celebrations (Tob. 8:20, 10:7). If we accept Heimpel's interpretation of a passage in ARM 2613 (see above), Šiptu is to stay up to five days before making her trek.

64 Skinner, Genesis, pp. 346-47. 
the series. With eloquent brevity, Rebekah passes it. ${ }^{65}$ Commentators have rightly connected her commitment with that of Abraham, who likewise left land and family on a divine command $(12: 1,4)$. Whether or not phenomenologically her statement is equivalent to Šiptu's sacrifice (see above) is difficult to assess.

\section{c. The Adieus (24:59-61)}

${ }^{59}$ So they sent off their sister Rebekah and her nurse along with Abraham's servant and his men. ${ }^{60}$ And they blessed Rebekah and said to her, "Our sister! May you grow into thousands of myriads; may your offspring seize the gate of its enemies." ${ }^{61}$ Then Rebekah and her maids arose, mounted the camels, and followed the man. So the servant took Rebekah and went his way.

So Rebekah gets to take her nanny as well as woman servants $(24: 61)$ to her new world, much like Princess Šiptu. There is nothing about drawing up marriage contracts, and that also is normal in interdynastic marriages where women and their families have little room to maneuver. Evidence for written marriage contracts is, in any case, missing from the Hebrew Bible (but see Tob. 7:14). ${ }^{66}$ We wish we had the words for bidding Šiptu adieu as she made her way to Mari. Would they have come close to what Rebekah heard? After the invocation ("Our sister," a term of endearment as well as kinship), hope is expressed for her fertility (ironic, given what we will later learn about Rebekah), but there is also the wish for her progeny's military success. The best parallel we have for these wishes is found in Ruth 4:11-12:

${ }^{11}$ All the people at the gate and the elders answered, "We are witnesses. May the LORD make the woman entering your home like Rachel and like Leah, the two who built up the House of Israel, so that you may prosper in Ephrathah and maintain a reputation in Bethlehem! ${ }^{12}$ May your house be like the house of Perez, whom Tamar bore to Judah, through the offspring that the LORD will give you by this young woman."

The blessing here echoes sentiments expressed with more detail in Psalm 45, a fine epithalamium honoring a king. In Ruth it is tripartite, addressing the bride (fertility), the groom (power and authority), and their posterity (worthy House), while the hopes expressed to Rebekah naturally lack any mention of the groom, since he is miles away. Some years ago, Simon Parker showed that when Ruth's concluding genealogy is taken into consideration, these blessings provide a good parallel with those the gods showered on King Keret (Kirta) and his bride. ${ }^{67}$ The good wishes Rebekah receives are interesting as well because they match what God desires for Abraham, just after he had passed the Akedah test (22:17), with Isaac surviving as his heir: ". . . [I will] make your descendants as numerous as the stars of heaven and the sands on the seashore. May your offspring seize the gate of its foes." The harmony in language may well heighten the appropriateness of a marriage between

65 In the aftermath, a principle came to be in Jewish practice that "women are not to be married without their consent" (Rashi).

66 We have actual contracts only from beyond Israel's border (Elephantine, fifth century B.C.E.) or after the early second century C.E. in Palestine (from Nahal Hever and Murabba'at). Westbrook erroneously speaks of an exchange of gifts after "the contract is concluded" in Genesis; see his Property and the Family in Biblical Law, JSOT Supplement Series 113 (Sheffield, 1991), pp. 146 and 149.

67 See his "The Marriage Blessing." I developed his comments as they apply to the Ruth blessings in Ruth: A New Translation, pp. 151-57. See also Aitken, "The Wooing of Rebekah," pp. 10-14. 
Rebekah and Isaac, but we must take note of the fact that here too Isaac is conspicuously absent and so also imagine that the conjunction of expressions has given the narrator another opportunity to sharpen the analogy between Rebekah and her father-in-law. ${ }^{68}$ When Isaac finally makes his entrance in this particular act, it is under baffling conditions.

\section{EPILOGUE: The Arrival (24:62-67)}

${ }^{62}$ Isaac had just come back from the vicinity of Beer-lahai-roi, for he was settled in the region of the Negeb. ${ }^{63}$ Isaac went out walking in the field toward evening and, looking up, he saw camels approaching. ${ }^{64}$ Raising her eyes, Rebekah saw Isaac. She alighted from the camel ${ }^{65}$ and said to the servant, "Who is that man walking in the field toward us?" And the servant said, "That is my master." So she grasped her veil to cover herself. ${ }^{66}$ The servant told Isaac all the things that he had done. ${ }^{67}$ Isaac then brought her into the tent, that of his mother Sarah. He took Rebekah as his wife; he loved her and found comfort after his mother's death.

Why Isaac was at Beer-lahai-roi when last he had been in Hebron is many a commentator's guess. Later (25:11) we are told that this is where he settled, but in that particular context there are many references to Ishmael, who is associated with this site (16:1-11). What Isaac was doing there and why he was doing it in the evening are also mysteries, the former question sharpened by a phrase containing an obscure verb in the infinitive (יצא) (לשוח seeking comfort for his mother's death and as burlesque as urinating or defecating (see the NEB!) ${ }^{70}$ The narrator appears keen to establish a strong link between the bride and groom as both (simultaneously) lift their eyes (נשא עינים, always used to highlight a suitable moment): he, to see approaching camels, she (presumably in a canopy), to look at Isaac, whatever he was doing. ${ }^{71}$ What happened to her as they lock eyes can also be disconcerting, the text

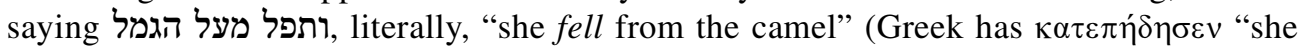
lept down"). Whereas men may jump off a moving chariot (2 Kings 5:21, but see 26, with a different verb) and women may ride on-and dismount from-donkeys (1 Sam. 25:23), the latter especially do not just "alight" from six-foot-high camels, at least not before the animals are made to crouch. Some traditional commentators find sinister consequences in her fall (loss of virginity among them), but most imagine that she was being polite, wishing to greet Isaac. Yet her fall occurred before the servant identifies Isaac as "my master." Perhaps this part of the episode is comically cathartic just before the story turns earnestly sentimental.

68 See Menorah Rotenberg, "A Portrait of Rebecca: The Devolution of a Matriarch into a Patriarch," Conservative Judaism 54 (2002): 46-62; Teugels, Bible and Midrash, pp. 119-29.

69 Touchingly, Rashi has Isaac there to retrieve Hagar so that she could minister to Abraham's old age. Abraham, however, was then (or soon would be) fathering a brood with Keturah (25:1).

${ }^{70}$ For these alternatives (citing many other suggestions as well), see Gregory Vall, "What Was Isaac Doing in the Field (Genesis XXIV 63)?," Vetus Testamentum 44 (1994): 513-23. Gary Rendsburg finds a reference here to the same organ as involved in the servant's oath to Abraham, "Lasûah in Gen. XXIV 63," Vetus Testamentum 45 (1995): 558-60. For John S. Kselman, Isaac was simply depressed; " "Wandering About' and Depression: More Examples," JNES 61 (2002): 275-77. In his "Depression in the Hebrew Bible: An Update," JNES 64 (2005): 187-92, Paul A. Kruger includes this Genesis passage among examples of depression. Most translations give "meditate" for the difficult verb, perhaps the most puzzling of proposed activities.

71 On this passage, Midrash Genesis Rabbah (at $55: 15$ ) is fairly racy, "R. Huna said: She saw his hand stretched out." 
On the ground, Rebekah learns the identity of the man approaching her. He is the servant's "master," hence her future husband. Rebekah "grasped her veil to cover herself" ותקח) (הצעיף ותתכס), bringing us back to the issue raised in this study's opening paragraph. Here we may explore a number of avenues, not necessarily contradicting each other. We might accept the traditional notion that she is doing it out of modesty, but, if so, we might have had notice of it as she joined the caravan. Given that women in ancient Israel likely did not wear a head cover (see nn. 1 and 2 above), we might cite the Mari report about the veiling of Šiptu as evidence that the notice concerning Rebekah may be vestigial, imported to Israel from narratives about royal marriages. As is the case in Mari, Rebekah's veiling would signal betrothal, the actual marriage not occurring until Isaac makes her his wife (24:67).

If so, what about the timing of the act? Why is Rebekah not veiled in Haran by the servant? Or if, as some commentators suggest, the act symbolizes the loss of virginity, why did Isaac not veil his bride in the fields of Beer-lahai-roi just before moving her into his mother's tent? To explain the timing, we must move out of our comparative inquiries and into historiographic motivations that are purely Hebraic. Rebekah had herself chosen to leave her land and, by veiling herself, takes control of the stories that will be told about her. Perhaps she remains conscious of the fact that, as footnoted above, in such marriages brides tend to come from the family with higher status than husbands. Not surprisingly, Rebekah replays Abraham's capacity to take changes and proves to be the most determined of Israel's matriarchs. Rare among Hebrew women, Rebekah can appeal directly to God (25:22-23) and, when armed with oracular prescience, can make harsh choices between sons, again like Abraham. Like Sarah, she has the resolve to force on a reluctant husband the fulfillment of God's promise (27).

Coda: it is too bad that the narrator does not reveal what the servant told Isaac. Would he have given us a new spin on how he choreographed the arrival of this veiled woman? Again we take note that the story by now seems to have left the conventions that encouraged its formulation, for we read nothing about the rounds of gift-giving that accompanied the arrival of princesses to their destined homes. ${ }^{72}$ Isaac now takes over in the final line of this long narrative, but it is Sarah who controls its sentiments. Isaac brings (hiphil of בוא) Rebekah into Sarah's tent, and, by making her his wife (לקח . . לאשה), sufficient love is kindled to nourish their marriage as well as to sustain the memory of another commanding matriarch, Sarah. ${ }^{73}$

72 See Lafont, "Relations internationales," p. 311.

73 Jonas Greenfield compares the vocabulary in 24:67 to that of the marriage scene in Keret (Kirta) CAT 1.15.ii.22-23: "Some Glosses on the Keret Epic," in Shalom M. Paul et al., eds., 'al Kanfei Yonah: Collected Studies of Jonas C. Greenfield on Semitic Philology (Jerusalem, 2001), pp. 870-71. When Ramses II saw his bride from Hatti, “. . . that she was beautiful of face, the foremost of women and courtiers, like a goddess, she was then beautiful in the heart of his majesty, and he loved her more than anything ..."; adapted from Alan R. Schulman, "Diplomatic Marriage in the Egyptian New Kingdom,” JNES 38 (1979): 186, n. 41 . 
